\title{
Comparative Research between France and India: A View from Within
}

\section{(Author's version)}

\author{
Stéphanie Tawa Lama
}

As a political scientist working on India, I am located, within French academia, in two fields where comparison is paradoxically under-theorised. Firstly, I belong in "comparative politics", a sub-discipline of political science whose name misleadingly suggests that comparison is central to this perspective. Yet until recently ${ }^{1}$, doing "comparative politics" actually meant that you specialize in the study of politics out of France; thus the notion was a proxy for the "study of non-western politics" (Ackerly \& Bajpai, 2017, p. 278). Secondly, I belong in "area studies", which also essentially means that I study the non-western world (the "West" being variously defined as France; or Western Europe; or Western Europe and North America). Area studies have been criticized indeed for their "anti-theory proclivities" (Chandhoke, 1996, p. 7), linked to the relative weakness of disciplinary concerns in this type of research. In both labels, therefore, lurks the idea that my research is defined, above all, by the "difference", at least in terms of (political) culture, of the country or region that I study; a difference that would seem to call for a comparison with the "non-different"; yet such comparison most often remains implicit, if not unconscious. Moreover, comparison is implicitly - but unmistakably - Eurocentric in both cases.

This under-development of comparison in both comparative politics and area studies, however, should be changing with the multiplication of international comparative projects that results from the new governance of academic research, and more specifically from the role of national and international funding agencies. But to what extent is it actually the case? In order to bring elements of answer to this question, the first section of this chapter, based on a preliminary analysis of international comparisons supported by the Agence Nationale de la Recherche

\footnotetext{
1 The contents of several academic journals specializing in comparative politics suggest that the comparative dimension is now taken more seriously. For instance, if three fourth of articles published in the Journal of Comparative Politics (http://icp.gc.cuny.edu/ ) focus on one country only, the proportion is one half for Comparative Political Studies (https://journals-sagepub-com.inshs.bib.cnrs.fr/loi/cpsa ) and only one third for the Revue Internationale de Politique Comparée (https://www-cairninfo.inshs.bib.cnrs.fr/revue-internationale-de-politique-comparee.htm ).
} 
(ANR), which is France's main research funding agency, will offer a broad overview of the geographical parameters of such projects (what countries, what regions are being preferably compared?). The second section, based on my experience as "principal investigator" in four comparative projects involving India, will further reflect on some of the practical and political problems attached to the "project culture" promoted by the new governance of academic research. Not least among them is the persistence, under new forms, of what Indian social scientists have denounced as "academic neo-colonialism" (Uberoi, 2000). This might come as a surprise, considering that in the past three decades, Indian scholars have played a major role in the development of postcolonial studies, thereby contributing to bringing up a more "pluri-centric academic world" (Das \& Randeria, 2015, p. 4), as recalled in section III. But even though concerns with "epistemic autonomy" (Roulleau-Berger, 2016) were expressed in the Indian academia from the 1960s onwards, and are gaining ground in several places today, section IV points at a series of facts suggesting that in comparative, collective research, eurocentrism does remain prevalent, albeit in new, more subtle forms.

\section{International comparisons and the new governance of academic research}

Project-based funding has become a major instrument of new public management (Aust, 2014, p. 2), and public research does not escape this general trend. In France, the ANR exemplifies the process of "agencification" that has characterised the reform of the state from the 1980s onwards (Bezes \& Lidec, 2016). The ANR is a central actor in the institutional recomposition and changing governance of the academic sphere, whereby the resources ${ }^{2}$ of research centres and individual researchers increasingly depend on their ability to successfully apply for funding from such funding agencies. This increasing importance of contract-based research in many countries goes along with the injunction of performance and relevance addressed to public research (Hubert \& Louvel, 2012, p. 15), which raises specific questions when such research is international.

The fact that in France as in many other countries, research funding is increasingly dependent on national agencies such as the ANR, or international ones such as or the European Research Council (ERC), partly explains why international, collective research projects are becoming a major mode of conducting social science research today. Agencies such as the

\footnotetext{
${ }^{2}$ Such resources are material but also symbolic: at stake are the means available to research teams in order to collect and analyse data, participate in international conferences to present their results and afford copy editing and translation services in view of publication, but also the prestige of the funded projects' coordinators or "principal investigators".
} 
ANR or the ERC - and the huge amounts of money that they allocate to various research teams through their selection process - often encourage the construction of partnerships between academic institutions located in different countries. If comparison always requires funding, this new mode of funding also encourages comparison insofar as building (or consolidating) "international partnerships" is one of the mantras of the new governance of world academia ${ }^{3}$. More specifically, "the large funding programmes, especially European ones, demand that partners have different nationalities, including partners from countries of the South" (Hubert \& Louvel, 2012, p. 23).

In order to objectify this phenomenon, I decided to look at ANR's data concerning the projects it has funded since its creation in 2005. Since the ANR did not respond to my requests for its own data analyses, I used two sources that are available online: the list of all funded projects since $2006^{4}$, and a document also produced by the ANR, taking stock of research programmes in social sciences funded between 2005 and $2016^{5}$.

Using "comparaison" (comparison) as a keyword first allowed me to identify 967 comparative projects funded between 2006 and 2017, pertaining to all disciplines ${ }^{6}$. Out of this first list, I removed those projects pertaining to other disciplines than the humanities and social sciences, and then I removed all non-international comparisons (i.e. comparisons within one country, between different models, different periods, different methods or different species) to arrive at a final list of a hundred international, comparative projects in social sciences.

The information available on the ANR website is limited: beyond the more or less explicit title of each project, I had access to a summary, more or less short, that usually (but not always) clarified what exactly is being compared. Table I, based on this limited information, offers a very broad classification of projects along geographic criteria. This table provides preliminary

\footnotetext{
${ }^{3}$ The ANR has specific collaborative programmes with agencies located in Germany, Japan and Quebec.

${ }^{4}$ http://www.agence-nationale-recherche.fr/suivi-bilan/rechercher-un-projet-finance/

${ }^{5}$ http://www.agence-nationale-recherche.fr/fileadmin/documents/2017/ANR-Bilan-SHS-Actionpublique.pdf

${ }^{6}$ Unfortunately, available data do not allow an estimation of the rate of success of comparative projects vis a vis non comparative ones. What we know is that the global rate of success since 2006 is $14.9 \%$ (https://jso2018.sciencesconf.org/data/pages/Presentation_Selection_ANR_Couperin .pdf); and that the proportion of social sciences and humanities in the projects funded by ANR is below $15 \%$ (whereas these disciplines concern about $28 \%$ of scholars) (Hubert \& Louvel, 2012, p. 17)
} 
answers to two questions that are of relevance to the idea of "decentering comparison": how big are international comparisons? And how far do they transcend, or not, the North-South divide?

Table I. International, comparative projects funded by the ANR (2006-2017)

\begin{tabular}{|c|c|c|c|c|c|c|c|c|c|c|c|}
\hline & $\begin{array}{l}2 \\
\text { States }\end{array}$ & $\begin{array}{l}3 \\
\text { States }\end{array}$ & $\begin{array}{l}4 \\
\text { States }\end{array}$ & $\begin{array}{l}5 \\
\text { States }\end{array}$ & $\begin{array}{l}7 \\
\text { States }\end{array}$ & $\begin{array}{l}8 \\
\text { States }\end{array}$ & $\begin{array}{l}9 \\
\text { States }\end{array}$ & $\begin{array}{l}1 \\
\text { continent }\end{array}$ & $\begin{array}{l}2 \\
\text { continents }\end{array}$ & $\begin{array}{l}\text { Non- } \\
\text { specified }\end{array}$ & Total \\
\hline $\begin{array}{l}\text { North- } \\
\text { North }\end{array}$ & 34 & 3 & 5 & 0 & 1 & 0 & 0 & 10 & 0 & 2 & 55 \\
\hline $\begin{array}{l}\text { North- } \\
\text { South }\end{array}$ & 3 & 6 & 5 & 1 & 0 & 0 & 1 & 0 & 8 & 0 & 24 \\
\hline $\begin{array}{l}\text { South- } \\
\text { South }\end{array}$ & 6 & 4 & 1 & 1 & 0 & 2 & 0 & 6 & 1 & 0 & 21 \\
\hline Total & 43 & 13 & 11 & 2 & 1 & 2 & 1 & 16 & 9 & 2 & 100 \\
\hline
\end{tabular}

Regarding the magnitude of comparisons, it appears that the vast majority of comparative projects involve two to four countries, the comparison between two countries being the most common one (43\%). Countries (or nation-states) are however not the only unit of comparison. A substantial minority of projects focus on continents, either to compare several sub-national regions within one continent $(16 \%)$, or to compare two continents $(9 \%)^{7}$.

If we turn to the North-South issue, it appears that a large half of projects go for a North-North comparison (55\%). The other half is almost equally divided between North-South comparisons (24\%) and South-South comparisons (21\%). Interestingly, among North-South comparative projects, one third involve a comparison between two continents.

\footnotetext{
7 We find here one example of the problems raised by "methodological nationalism" (Beck, 2007) in comparative research (see Giraud \& Lallement in this volume). The tendency to consider nation-states as the default unit of comparison makes it difficult to compare India - a federal state on the scale of a continent, characterised by strong internal diversity (linguistic, religious, cultural) - with a single European state; and while a comparison between India and the European Union would make sense on many topics, no such comparison appears in projects funded by the ANR. Instead, in comparative projects involving India, the "Indian case" is usually based on two to four case studies of Indian provinces or cities.
} 
Unfortunately, the fact that the ANR ignored my request to consult its own data analysis which is consistent with the general opacity of the selection process and of the criteria used by the agency - makes it difficult, at this stage, to go beyond this rough observation.

\section{The problems with (comparative) "project culture"}

Research in social sciences (as in other sciences) highly depends on material contingencies. K.K.Patel's chapter in this volume addresses the role of political and geopolitical factors in providing those resources that enable the shaping of new research fields. To complement this view "from above", I would like here to consider the conditions of production of international comparisons at a very basic, concrete level, i.e. to offer a "view from within".

International comparison, as it is practiced within the project culture associated with the new governance of research, raises two types of issues: (i) practical difficulties that could be overcome more easily if these were not so systematically under-estimated, if not outright ignored; and (ii) more political issues attached to the role assigned to research, and to the status offered respectively to researchers from the North and from the South in collective projects that are mostly funded by agencies of the North. Altogether, such issues therefore concern the quality, the objectives and the politics of international comparative research.

On the basis of my own experience as "principal investigator" in four international, comparative projects, I have observed that international comparison involves a series of differences that seriously complicate comparative work. I have been (co)coordinator of four such projects (two finished, one ongoing, one never fully implemented for lack of funding). As shown in Table 2, these four India-centric, comparative projects focused respectively on public policy (electoral quotas for women), urban governance, and political discourses and practices (new forms of political representation). Two of these projects offered a comparison within India, and two compared India with other countries; all four projects were funded by French (and sometimes other Western countries') institutions.

Table 2. Four India-centric comparative projects

\begin{tabular}{|c|c|c|c|c|c|c|c|}
\hline Title, date & Object & Basis & $\begin{array}{l}\text { Number } \\
\text { of team } \\
\text { member } \\
s\end{array}$ & $\begin{array}{l}\text { Nationalitie } \\
\mathrm{s}\end{array}$ & $\begin{array}{l}\text { Discipline } \\
\mathrm{s}\end{array}$ & $\begin{array}{l}\text { Types of data } \\
\text { analysed }\end{array}$ & $\begin{array}{l}\text { Funding } \\
\text { agency }\end{array}$ \\
\hline $\begin{array}{l}\text { Women and } \\
\text { Local } \\
\text { Government } \\
\text { in Urban India. } \\
\text { The } \\
\text { Implementatio } \\
\text { n and Impact } \\
\text { of Women's } \\
\text { Reservations } \\
\text { in the } \\
\text { Municipal } \\
\text { Corporations }\end{array}$ & $\begin{array}{l}\text { Electoral } \\
\text { quotas for } \\
\text { women in } \\
\text { Indian } \\
\text { municipalities }\end{array}$ & $\begin{array}{l}\text { Delhi, } \\
\text { Mumbai, } \\
\text { Chennai, } \\
\text { Kolkata }\end{array}$ & 2 & $\begin{array}{l}\text { French } \\
\text { Indian }\end{array}$ & $\begin{array}{l}\text { Political } \\
\text { science } \\
\text { Economics }\end{array}$ & $\begin{array}{l}\text { Interviews } \\
\text { Direct } \\
\text { observation } \\
\text { Questionnaire } \\
\mathrm{s}\end{array}$ & $\begin{array}{l}\text { Ford } \\
\text { Foundatio } \\
\mathrm{n} \\
\text { CIDA } \\
\text { (Sweden) }\end{array}$ \\
\hline
\end{tabular}




\begin{tabular}{|c|c|c|c|c|c|c|c|}
\hline $\begin{array}{l}\text { of Delhi, } \\
\text { Mumbai, } \\
\text { Chennai } \text { and } \\
\text { Kolkata }^{8} \\
\text { 2001-2002 }\end{array}$ & & & & & & & \\
\hline $\begin{array}{l}\text { Acteurs, } \\
\text { politiques et } \\
\text { gouvernance } \\
\text { urbaines. Les } \\
\text { processus } \\
\text { décisionnels } \\
\text { gouvernant } \\
\text { l'offre et la } \\
\text { demande de } \\
\text { biens et de } \\
\text { services } \\
\text { collectifs dans } \\
\text { quatre } \\
\text { métropoles } \\
\text { indiennes } \\
\\
2002-2007\end{array}$ & $\begin{array}{l}\text { Urban } \\
\text { governance, } \\
\text { post- } \\
\text { liberalisation } \\
\text { and post- } \\
\text { decentralizatio } \\
\text { n }\end{array}$ & $\begin{array}{l}\text { Delhi, } \\
\text { Mumbai, } \\
\text { Hyderabad, } \\
\text { Kolkata }\end{array}$ & 11 & $\begin{array}{l}\text { French } \\
\text { Indian } \\
\text { Dutch }\end{array}$ & $\begin{array}{l}\text { Political } \\
\text { science } \\
\text { Economics } \\
\text { Geography } \\
\text { Urban } \\
\text { studies }\end{array}$ & $\begin{array}{l}\text { Interviews } \\
\text { Direct } \\
\text { observation } \\
\text { Public } \\
\text { statistics } \\
\text { Political } \\
\text { debates }\end{array}$ & $\begin{array}{l}\text { French } \\
\text { ministry of } \\
\text { higher } \\
\text { education }\end{array}$ \\
\hline $\begin{array}{l}\text { Democracy } \\
\text { and } \\
\text { governance in } \\
\text { India and } \\
\text { South Africa: } \\
\text { a comparative } \\
\text { study of the } \\
\text { role of } \\
\text { political ol } \\
\text { participation } \\
\text { in the } \\
\text { governance of } \\
\text { big cities }{ }^{10} \\
2008-2009\end{array}$ & $\begin{array}{l}\text { Participation in } \\
\text { urban } \\
\text { governance }\end{array}$ & $\begin{array}{l}\text { India (Delhi, } \\
\text { Mumbai, } \\
\text { Kolkata) and } \\
\text { South Africa } \\
\text { (Johannesbur } \\
\text { g, Cape Town, } \\
\text { Durban) }\end{array}$ & 20 & $\begin{array}{l}\text { French } \\
\text { Indian } \\
\text { South } \\
\text { African }\end{array}$ & $\begin{array}{l}\text { Political } \\
\text { science } \\
\text { Economics } \\
\text { Geography } \\
\text { Urban } \\
\text { studies } \\
\text { Sociology }\end{array}$ & $\begin{array}{l}\text { Interviews } \\
\text { Direct } \\
\text { observation } \\
\text { Political } \\
\text { debates }\end{array}$ & $\begin{array}{l}\text { None for } \\
\text { the whole } \\
\text { project }^{11}\end{array}$ \\
\hline $\begin{array}{l}\text { New Political } \\
\text { Representativ }\end{array}$ & $\begin{array}{l}\text { New forms of } \\
\text { political } \\
\text { representation }\end{array}$ & $\begin{array}{l}\text { France, } \\
\text { Germany, } \\
\text { Brazil, India, } \\
\text { China } \quad(2-3\end{array}$ & 13 & $\begin{array}{l}\text { French } \\
\text { Indian }\end{array}$ & $\begin{array}{l}\text { Political } \\
\text { science } \\
\text { Sociology }\end{array}$ & $\begin{array}{l}\text { Interviews } \\
\text { Direct } \\
\text { observation }\end{array}$ & ANR-DFG \\
\hline
\end{tabular}

8 See Ghosh, Archana \& Tawa Lama-Rewal, Stéphanie, Democratization in Progress. Women and Local Politics in Urban India, Delhi, Tulika, 2005, 158 p.

${ }^{9}$ See Ruet Joël \& Tawa Lama-Rewal Stéphanie (ed), Governing India's Metropolises, Delhi, Routledge, 2009, $315 p$.

10 See Bénit-Gbaffou, Claire, \& Tawa Lama-Rewal, Stéphanie "Local democracy in Indian and South African cities: A comparative literature review", in Isabel Hofmeyr and Michelle Williams (Eds), South Africa and India: Shaping the Global South, Johannesburg, Wits University Press, 2011, pp. 176-196. Also Tawa Lama-Rewal, Stéphanie \& Marie-Hélène Zérah (ed.), "Rethinking Urban Democracy in South Asia", SAMAJ http://samaj.revues.org/index3176.html 2011.

11 This project was initially supported by two French research centres (in Delhi and in Johannesburgh), but this funding allowed only the organisation of two workshops. Organisers then applied for funding from the ANR, the CNRS (National Centre for Scientific Research) and AFD (French Agency for Development); but after meeting with a series of rejections, they had to suspend the project indefinitely. 


\begin{tabular}{|l|l|l|l|l|l|l|l|}
\hline $\begin{array}{l}\text { e Claims: A } \\
\text { Global View 12 }\end{array}$ & $\begin{array}{l}\text { cities in each } \\
\text { country) } \\
\text { 2016-2019 }\end{array}$ & & German & & $\begin{array}{l}\text { Political } \\
\text { debates } \\
\text { Brazilian }\end{array}$ & \\
\hline
\end{tabular}

My involvement in this series of comparative endeavours (along with many informal discussions with colleagues also engaged in international projects) led me to identify three challenges born from the very international nature of these projects.

The first challenge concerns the fact that members of an international team are used to working in different languages. This might explain the importance of comparisons conducted within one continent, as shown in Table 1. This is also observed by Sil and Ahram in a paper advocating the development of "comparative area studies":

"Small-N studies are ... far more prevalent within world regions than across them, particularly such regions where a single language can help conduct research in multiple cases. We see this in research on Latin America, where Spanish is used everywhere except Brazil (e.g. Collier and Collier 1991; Mahoney 2010a), sub-Saharan Africa with its many Anglophone and Francophone countries (e.g. Elischer 2013; Stroh 2014), the Middle East with the prevalence of Arabic (Bank et al. 2015; Lynch 2012), and the former Soviet Union, where Russian is still handy for interviews and archival research (Hale 2014; Luong 2002)" (Sil \& Ahram, 2018)

Even when English becomes the working language of all members in an international project (which is often, but not always the case), much is lost in translation. In today's globalised academia, this might well seem a trivial concern. However, this fact necessarily implies that the writing - if not the thinking - of research is bound to lose some subtlety as it becomes international. Acknowledging this linguistic impoverishment should in no way prevent us from engaging into collaborative research with people whose working language is different from ours; but we should address this problem by devoting specific resources (time, money, even "outcomes") to working, for instance, on the collective construction of a critical, common vocabulary regarding the key ideas/concepts of the project. Indeed "the definition and understanding of concepts and the relationship between concepts and contexts are of critical concern in comparative research that crosses national, societal, cultural and linguistic boundaries" (Hantrais, 2008, p. 72).

For instance, while comparing the political and academic debates that took place in South Africa and India concerning local democracy in an urban context, Claire Bénit-Gbaffou and I

\footnotetext{
12 See http://ceias.ehess.fr/index.php?3973
} 
realized that the apparently neutral notion of "resident" carried very different connotations, with concrete consequences, in the two contexts:

"In India, the unequal legitimacy of various categories of urban mobilizations is revealed by the implicit, but very strong, connotations of the various terms used to qualify urban dwellers... "Residents", in the Indian contemporary context, implies legality and excludes squatters - who form anywhere between one fourth and one third of the population of megacities. Moreover "residents" are now associated to "resident welfare associations", which conjure up an image of middle class colonies, as opposed to "slum dwellers" ... By contrast, "resident" has become a neutral term in South African urban society - although when referring to civil society a more commonly used term is the one of "community" ... It has not always been the case, however, as the right of residence in South African cities (considered ultimately "white spaces" where Black people had only a temporary right to stay under apartheid) was restricted to Whites and Blacks having a permit. In post-apartheid South Africa, it is not politically possible to deny anyone the title of local "resident" (even if living in an informal settlement, and even if undocumented migrant). This also explains why residents of informal settlements do have rights in South African cities (notification of eviction, relocation, etc.) - even though most of them are not aware of them nor able to access them if not having political and social resources- which contrasts to the situation of informal dwellers in Indian cities." (Bénit-Gbaffou \& Tawa Lama-Rewal, Stéphanie, 2011, p. 193)

The second challenge of international comparative research is linked to the often multidisciplinary nature of these projects. The fact that team members have been trained in different disciplines doubtlessly makes it possible to enlarge perspectives, and to avoid excessive reductionism. But different disciplines will have different definitions of the same concept. For instance, the concept of "governance" does not have the same connotations for a political scientist and for an economist. The former will spontaneously link it to issues of governability, if not to the Foucaldian concept of governmentality (Lascoumes, 2004), while the latter will more likely associate it to notions of management and regulation (Jessop, 1995). In this particular case, the explicitation of the different origins and meanings of the concept is essential to an analysis of its ubiquitous use and political effects today. Therefore, my point here is not that we should avoid working with scholars from other disciplines, but that we must question, early in the collective work, the ambiguities, misunderstandings and blind spots that might result from such pluri-disciplinarity.

The third challenge appears even when the international team is composed of scholars belonging in the same discipline: it is related to the fact that academic cultures are different in 
different countries. Thus the contours of political science, as a discipline, are much larger in France (where it tends to appropriate the methods, types of data and references of neighbouring disciplines such as anthropology and sociology) than in Germany. And the status of fieldwork is much more central for French political scientists than for their Indian colleagues. New interdisciplinary fields such as urban studies or gender studies take these three challenges to a higher level. For instance, I discovered during the project on the impact of women's quotas in Indian municipal corporations that the concept of gender has substantially different meanings for two specialists of gender studies, when one is a political scientist trained in France, and the other an economist trained in India (in the field of development studies). Archana Ghosh and I indeed sometimes found it difficult to agree about when to say "women" and when to say "gender" while we were writing together the book presenting our research results (Ghosh \& Tawa Lama-Rewal, 2005). This divergence is well captured by Nivedita Menon who reflects on how the use of the concept of gender has evolved in India since the 1970s. While gender was initially meant to "destabilize the biological category of 'sex"', she writes, the relationship between women and gender was progressively stabilized again, from the 1990s onwards, by development policies that conflate the two concepts: "Many feminists and women's movement activists in India have been struck by the general acceptability of the word 'gender' in the corridors of state power over the 1990s (Tharu and Niranjana, 1999). The term has been domesticated and has become a synonym for 'women'”(Menon, 2009, p. 11). Thus by imposing a collaboration between people trained in different disciplines, different countries and different languages, international comparative projects force their participants to exit their professional comfort zone, change their focus, consider new concepts (or new definitions of known concepts), new methods, new data, new references and new ways of working. All these constraints have the potential of being intellectually fruitful, but when they are not seriously addressed, they are more likely to be intellectually crippling. Comparison in social sciences still suffers from a lack of reflexivity when it comes to its concrete modus operandi in such projects. Instead of just coping with these difficulties, we should engage with them. For if we do not give ourselves (or demand) the means to adequately address these challenges, we can only end up with highly imperfect "deliverables" that remain forever exploratory.

Besides these practical aspects, the second type of issues raised by the increasing role of funding agencies in scientific research is almost existential: the funding process, through calls for applications on a pre-determined broad topic, channels research towards directions decided by the agency, through various committees composed of academics but also of government representatives. Indeed, even though the ANR was not the first research funding agency in France, its creation marked a decisive step in separating the functions of funding 
and planning (devolved to such agencies in France as in Germany or in the UK), and those of implementing research programmes, devolved to universities and research institutions (Hubert \& Louvel, 2012, p. 16) In this process research becomes less and less fundamental and more and more applied. Even though, in France, researchers are not yet requested to come up with policy recommendations in the conclusion of their investigations, this is a significant turn in the role assigned to research and researchers ${ }^{13}$.

This phenomenon - and the critiques it evokes - is international. Thus the sociologist Patricia Uberoi recalls that as early as the 1970s, Indian scholars debated about the relevance of sociology, and about the role of sociologists - as social engineers, social interpreters, or social critics (Béteille, 1972) ${ }^{14}$. But four decades later, she writes,

"Forced to go where the funding is, the sociologists' research priorities and criteria of relevance are determined by the sponsoring agencies, whether government or, increasingly, the big, extra- and multinational funding agencies. Each has its attendant hazards, but in either case, the role of sociology as social engineering is likely to prevail, for every project - if it is not to be deemed infructuous, is expected to yield a clear set of policy implications and recommendations." (Uberoi, 2000, p. 10)

Finally, the location of most funding agencies in the global North has political implications: it is reflected, in international comparative projects, in the different roles assigned to scholars from the North (who are almost always the "principal investigators") and scholars from the South. In other words, the role of funding agencies reinforces the asymmetry between academics, as underlined by Uberoi again:

“... cross country comparative projects, though often lushly funded, tend to be devised without consultation with the Indian partners who are merely expected to execute the Indian 'country study' according to a determined protocol" (Uberoi, 2000, p. 10)

Uberoi further denounces what she considers as "the academic neo-colonialism of the project culture" (Uberoi, 2000, p. 10). This might appear surprising, coming from a country that has spectacularly contributed to "provincializing Europe" (Chakrabarty, 1992).

\footnotetext{
${ }^{13}$ However, the ANR has, under pressure, progressively increased the proportion of "white programs", i.e. programs that are not thematic.

${ }^{14}$ Michael Burawoy' (Burawoy, 2005) defence of "public sociology" and his distinction between the instrumental and reflexive uses of this discipline appear as a direct elaboration of Béteille's argument.
} 


\section{The Indian contribution to a "pluri-centric academic world"}

A series of collective works have recently offered a reflexive perspective on the theoretical and practical dimension of social sciences in India since its independence (1947), with a focus on sociology and anthropology (Deshpande, Sundar, \& Uberoi, 2000; Patel, 2016; Uberoi, Sundar, \& Deshpande, 2008). These retrospective analyses show that as early as the 1960s - a moment characterised in India by the fast development of higher education institutions Indian social scientists were alert to the pitfalls of academic colonialism; indeed in a piece published in 1968 in the Delhi-based journal Seminar, J.P.S. Uberoi, an eminent sociologist, invited his colleagues to aim at "academic swaraj" (Uberoi, 2000). The Hindi word swaraj literally means "self-government"; this word also immediately evokes the famous essay whereby Mohandas Karamchand Gandhi launched his decisive implication in India's anticolonial movement, Hind Swaraj, (translated as "Indian Home rule", 1909). According to Sujata Patel, this was a moment when

"Sociologists in India saw their project as that which analyses one's own society (India) in one's (indigenous) 'own terms', without colonial and now neo-colonial tutelage" (Patel, 2016, p. xxiv)

The phrase "academic swara" thus appears as the forerunner of the injunction to "decolonize the mind" (Thiong'o, 1986), with a focus on the academic dimension of intellectual life. This phrase also anticipates the idea of "epistemic autonomy" (Roulleau Berger 2016) promoted in a recent book about "post-western sociology".

A crucial link between JPS Uberoi's injunction in the late 1960s, and the increasing influence, today, of post-colonial studies (of which Thiong'o is a major literary figure, and post-western sociology a recent outcome), is the subaltern studies, a collective intellectual endeavour born in the late 1970s in the field of Indian historiography. Around the Marxist historian Ranajit Guha, young scholars such as Dipesh Chakrabarty, Partha Chatterjee or Shahid Amin then decided to reverse the "nationalist" as well as the "imperial" perspectives on Indian history through a new assessment of the role of "subalterns" in India's anti-colonial movement. While a description of subaltern studies is beyond the scope of this paper ${ }^{15}$, of importance here is the fact that this intellectual collective was a central incubator of post-colonial studies, characterised by a critique of euro-centrism in the dominant discourses on former colonised societies - be it artistic, political or scientific discourse (Pouchepadass, 2000). Chakrabarty's book, "Provincialising Europe" (2000), indeed played an important role in the increasing popularity of the post-colonial perspective. In this book the historian describes and analyses

\footnotetext{
${ }^{15}$ For a selective and retrospective presentation of subaltern studies, see (Ludden, 2002)
} 
both the causes and the consequences of the asymmetry of knowledge, and therefore of ignorance, that characterises intellectual exchanges between the "West and the rest" (Hall, 1992).

One must note however that subaltern studies have constantly evoked criticism, first in India ${ }^{16}$ and then on the global stage. The most recent critique has come from the sociologist Vivek Chibber, who considers that post-colonial theory, excessively fascinated by the diversity of cultural forms of social organisation, actually ends up renewing cultural essentialism. For him it is crucial, both from a scientific and a political perspective, to keep analysing non-Western societies with the same categories used to explain the West (for instance: class, capitalism) (Chibber, 2013).

One can see therefore that there exists an old, rich debate on the problems of comparison and of its centering/decentering, the importance of contexts and that of commensurability, a debate in which Indian authors, or at least authors of Indian origin (more on this later) have played a major role. However, this dense theoretical debate does not seem to find adequate translation in concrete comparative projects.

When it comes to comparisons in political science, for instance, an article by political theorist Neera Chandhoke conveys a feeling of frustration at the persisting indeterminacy of comparative political analysis, still rooted in colonialism, still west-centric, still excessively reductionist (Chandhoke, 1996). About two decades later, Ackerly \& Bajpai seem to answer Chandhoke's dark assessment: indeed they propose, as a way to avoid "epistemological imperialism", to enlarge the canon of "comparative political thought" by opening it to contributions of the post colonial, feminist and queer scholarship, and by considering not only non-western sources, but also non-elite texts and actions (Ackerly \& Bajpai, 2017, p. 286). An important contribution in this regard is offered by Amartya Sen's endeavour to document a series of experiments that can be qualified as democratic lato sensu in the pre-colonial history of the Indian subcontinent. Indeed Sen highlights the existence of a very old "dialogic tradition " in which "public reasoning" went along with "argumentative heterodoxy" (Sen, 2005, p. 13), a tradition that started with Buddhist councils, the most important of which took place under Emperor Ashoka, in the third century AD.

\footnotetext{
${ }^{16}$ In the 1980s, critiques focused on the inherent vagueness of the category of "subaltern"; later they turned to the increasing focus on (colonial) discourse under the influence of cultural studies. See (Sarkar, 1997).
} 


\section{The persisting challenges to "epistemic autonomy"}

The notion of epistemic autonomy is elaborated by Laurence (Roulleau-Berger, 2016) in a book that offers examples and an agenda for the development of a "post-western sociology", i.e. "a world science building on all strands of thought, whatever their origin" (Schemeil, 2015), which implies recognising the equal legitimacy of various scientific cultures.

This new perspective is central to the emergence of "a pluri-centric academic world" (Das \& Randeria, 2015), in which India is certainly one of the new centres, along with China, Europe and North America. However, several elements point to the fact that some centres are more central than others.

Regarding India's academic centrality, one must first distinguish, among Indian intellectuals, those who are "at home in diaspora" (Assayag \& Benei, 2003), that is, academics born and primarily educated in India, but holding today eminent positions in the most prestigious American or British universities. Arjun Appadurai, Gayatri Spivak or Amartya Sen are the most visible of these global intellectuals - i.e. intellectuals who are recognized as central, authoritative voices on general topics apprehended on a global scale, such as history, culture, or the subalterns. But there are many other Indian intellectuals (institutionally located in India, but also in more peripheral universities in the West), who are assigned the status of local intellectuals: that is, their work or their voice is considered as provincial, informative. Thus if globalization of academia does complicate the international division of scientific labour, it does not abolish it.

One striking example of the contrast and hierarchy between global and local intellectuals is provided by Wiebke Keim (Keim, 2010) through an examination of the topics of conferences given by invited scholars from various countries in a relatively prestigious French university, namely the Ecole des Hautes Etudes en Sciences Sociales (EHESS, School for Advanced Studies in Social Sciences) in Paris. The contrast she highlights between scholars who are invited as "authorities" and scholars who are invited as "informants" echoes Koselleck's distinction between the local historian (who narrates), the regional historian (who compares) and the global historian (who explains) ${ }^{17}$. This observation confirms Das and Randeria's remark that "sociological scholarship in and from India" does not have the same disciplinary status in India and abroad. In Western academia indeed, it has been received "in the discipline of anthropology, non-European history or cultural studies" (Das \& Randeria, 2015, p. 4).

\footnotetext{
17 (Koselleck, 2011) quoted in (Schemeil, 2015).
} 
Interestingly, the hierarchy implicit in this requalification (which is also a disqualification) of scholarship from non-Western countries can be observed in India too:

“(...) in India sociology has always been taught in a comparative perspective, albeit comparisons with other non-Western regions and traditions of scholarship are conspicuous by their absence" (Das \& Randeria, 2015, paragr. 5)

A recent trend, however, suggests that this might be changing: one has observed, in the past ten years, a multiplication of research projects (or research events such as conferences and seminars) focusing on a comparison between India and China. This trend indicates a growing interest, by funding agencies (that can be Western, Chinese or - less often - Indian), in these two major "emerging countries". The India-China comparisons in fact exemplify the political stakes of international comparison. Insofar as comparing two (or more) countries implies that one considers them as comparable, the inclusion in a comparative scheme means inclusion in a category of countries. In this regard, the inclusion of the Indian case in large comparative projects on democracy is significant of a new acknowledgement that India, for all its limitations, is one of the great democracies of today. Further, measuring a given phenomenon in two countries can be a way for the two countries to measure up to one another. India-China comparisons can then be seen as one of the many ways through which the two countries compete as Asian powers, India's political advantage (as a democracy) being pitted against China's economic one (as a place of high growth).

\section{Conclusion}

I have tried in this chapter to examine the current practice of comparison in social sciences from what I might call a "multi-situated" perspective, namely: as a French scholar belonging in political science and in area studies; as a principal investigator in four comparative projects involving (in various capacities) France and India; and as an India specialist interested in Indian scholarship and its reception, both in the subcontinent and in the global North. Even though the data on which this analysis is based are limited - to the French ANR, to my own experience and to a part of the Indian debate on academic colonialism -, looking at the conditions of, and the reflexion on comparative research from these various perspectives leads me to three tentative conclusions.

Firstly, the new governance of academic research and its emphasis on what I call, following Patricia Uberoi, the project culture, does encourage comparisons not only between countries of the global North, but also between the global North and the global South, and within the global South. Secondly, despite the large budgets that are generally allocated to such 
comparative projects, it appears that they often fail to adequately address three types of issues: (i) practical issues regarding the conditions of production of comparative research that are, if not ignored altogether, at least under-theorised; (ii) existential issues regarding the ultimate objectives of research in social sciences and therefore the role of researchers; and (iii) political issues regarding the roles assigned respectively to scholars from the North and scholars from the South in these projects. Thirdly, this state of affairs shows that international comparative projects remain largely disconnected from international debates about the necessary pluri-centrism of academia and the associated claims to epistemic autonomy.

\section{References}

Ackerly, B., \& Bajpai, R. (2017). Comparative Political Thought. In A. Blau (Éd.), Methods in Analytical Political Theory (p. 270- 296). Cambridge ; New York: Cambridge University Press.

Assayag, J., \& Benei, V. (2003). At Home in Diaspora: South Asian Scholars and the West. Bloomington: Indiana University Press.

Aust, J. (2014). Financer la recherche sur projet. Figures historiques d'un dispositif de gouvernement. Geneses, $n^{\circ}$ 94(1), 2 - 6.

Beck, U. (2007). The Cosmopolitan Condition: Why Methodological Nationalism Fails. Theory, Culture \& Society, 24(7- 8), 286- 290.

Bénit-Gbaffou, C., \& Tawa Lama-Rewal, Stéphanie. (2011). Local democracy in Indian and South African cities: A comparative literature review. In South Africa and India: Shaping the Global South (Wits University Press, p. 176- 196). Johannesburg: Isabel Hofmeyr and Michelle Williams.

Béteille, A. (1972). The problem. Seminar, (157), 11- 12.

Bezes, P., \& Lidec, P. L. (2016). Politiques de l'organisation. Revue francaise de science politique, Vol. 66(3), 407- 433.

Burawoy, M. (2005). For Public Sociology. American Sociological Review, 70(1), 4- 28.

Chakrabarty, D. (1992). Provincializing Europe. Postcolonial Thought and Historical Difference. Princeton: Princeton University Press.

Chandhoke, N. (1996). Limits of Comparative Political Analysis. Economic and Political Weekly, 31(4), PE2- PE8.

Chibber, V. (2013). Postcolonial Theory and the Specter of Capital (1 edition). London: Verso. 
Das, V., \& Randeria, S. (2015). Social sciences and public debates: The case of India. Socio. La Nouvelle Revue Des Sciences Sociales, (5), 81 - 98.

Deshpande, S., Sundar, N., \& Uberoi, P. (Éd.). (2000). SITUATING SOCIOLOGY. A symposium on knowledge, institutions and practices in a discipline (Seminar). Consulté à l'adresse http://www.india-seminar.com/semframe.html

Ghosh, A., \& Tawa Lama-Rewal, S. (2005). Democratization in Progress. Women and Local Politics in Urban India. Delhi: Tulika Books.

Hall, S. (1992). The West and the Rest: Discourse and Power. In S. Hall \& B. Gieben (Éd.), Formations of Modernity (p. 275- 332). Cambridge: Polity Press.

Hantrais, L. (2008). International Comparative Research: Theory, Methods and Practice. Basingstoke England; New York: Palgrave.

Hubert, M., \& Louvel, S. (2012). Le financement sur projet : quelles conséquences sur le travail des chercheurs? Mouvements, $n^{\circ} 71(3), 13-24$.

Jessop, B. (1995). The regulation approach, governance and post-Fordism: alternative perspectives on economic and political change? Economy and Society, 24(3), 307- 333.

Keim, W. (2010). Analyse des invitations de chercheurs étrangers par l'EHESS. Compétences reconnues et clivages Nord-Sud. Cahiers de la recherche sur l'éducation et les savoirs, (9), 33- 52.

Koselleck, R. (2011). L'expérience de l'histoire. Paris: Points.

Lascoumes, P. (2004). La Gouvernementalité : de la critique de l'État aux technologies du pouvoir. Le Portique. Revue de philosophie et de sciences humaines, (13-14). Consulté à l'adresse http://journals.openedition.org/leportique/625

Ludden, D. (2002). Reading Subaltern Studies: Critical History, Contested Meaning and the Globalization of South Asia. Anthem Press.

Menon, N. (2009). sexuality, caste, governmentality: contests over 'gender' in India. Feminist Review, 91(1), 94- 112.

Patel, S. (2016). Doing Sociology in India: Genealogies, Locations, and Practices (OIP). Oxford, New York: Oxford University Press.

Patrick, Sil, R., \& Ahram, A. (2018, août 24). Comparative Area Studies: What It Is, What It Can Do. 31. Hamburg. 
Pouchepadass, J. (2000). Les Subaltern Studies ou la critique postcoloniale de la modernité. L'Homme. Revue française d'anthropologie, (156), 161-186.

Roulleau-Berger, L. (2016). Post-Western Revolution in Sociology: From China to Europe. Leiden, Boston: BRILL.

Sarkar, S. (1997). The Decline of the Subaltern in Subaltern Studies. In Wrting Social History (p. 82-108). Delhi: Oxford University Press.

Schemeil, Y. (2015). Une science politique non occidentale existe-t-elle? Socio. La nouvelle revue des sciences sociales, (5), 163-188.

Sen, A. (2005). The Argumentative Indian. Writings on Indian Culture, History and Identity. Noida: Penguin books.

Thiong'o, N. W. (1986). Decolonising the Mind (Studies in African Literature edition). London : Portsmouth, N.H: Heinemann.

Uberoi, P. (2000). Deja vu? Seminar, 495. Consulté à l'adresse http://www.indiaseminar.com/semframe.html

Uberoi, P., Sundar, N., \& Deshpande, S. (2008). Anthropology in the East: founders of Indian sociology and anthropology. Seagull. 